Pobrane z czasopisma Annales $\mathrm{H}$ - Oeconomia http://oeconomia.annales.umcs.pl

Data: 26/04/2023 03:15:34

DOI:10.17951/h.2019.53.4.141-152

\begin{tabular}{lc}
\hline & A N N A L E S \\
UNIVERSITATIS MARIAE CURIE-SKŁODOWSKA \\
LUBLIN - POLONIA \\
VOL. LIII, 4 \\
SECTIO H
\end{tabular}

BŁAŻEJ SOCHA

blazej.socha@uni.lodz.pl

Uniwersytet Łódzki. Wydział Zarządzania

ul. J. Matejki 22/26, 90-237 Łódź, Polska

ORCID ID: https://orcid.org/0000-0002-2422-6851

DARIUSZ URBAN

dariusz.urban@uni.lodz.pl

Uniwersytet Łódzki. Wydział Zarządzania

ul. J. Matejki 22/26, 90-237 Łódź, Polska

ORCID ID: https://orcid.org/0000-0003-0500-1830

\title{
Przejawy finansyzacji polskich spółek giełdowych w opinii menedzerów. Wyniki badań własnych
}

Symptoms of Polish Listed Companies' Financialization from the Managers' Perspective.

Empirical Findings

Keywords: financialization; listed companies; qualitative analysis

Słowa kluczowe: finansyzacja; spółki giełdowe; badania jakościowe

JEL: D22; F65; G30

Propozycja cytowania: Socha, B., Urban, D. (2019). Przejawy finansyzacji polskich spółek giełdowych w opinii menedżerów. Wyniki badań własnych. Annales Universitatis Mariae Curie-Skłodowska, sectio H-Oeconomia, Vol. 53, No. 4. 


\begin{abstract}
Theoretical background: The article discusses the issue of financialization defined as partial decoupling of the financial sector from the real economy. This phenomenon can be considered from the point of view of economies, markets (including commodity markets), financial and non-financial companies as well as household. The article deals with the issue of financialization of Polish listed companies. The main symptom of this phenomenon is increased importance of financial operations in the process of generating added value. Purpose of the article: To assess the declarative degree of financialization of selected listed companies as well as to identify factors that may be related to the phenomenon of financialization in the analyzed entities. Research methods: The analysis of literature and presentation of the results of authors' own qualitative research. In the empirical part, the measures of central tendency, classification based on the k-means method and the Mann-Whitney U test were used.

Main findings: The obtained results suggest that the phenomenon of financialization does not seem to play a significant role in shaping the operating activity of Polish listed companies from the analyzed sectors. In addition, it was shown that the innovative potential, market position, size of the company and sales markets may be related to the degree of finanacialization. This paper contributes to the national literature with the phenomenon of financialization of non-financial enterprises in the context of changes taking place in the enterprise from the financial managers' perspective.
\end{abstract}

\begin{abstract}
Abstrakt
Uzasadnienie teoretyczne: Artykuł dotyczy kwestii finansyzacji rozumianej jako częściowe odseparowanie sfery finansowej od sfery realnej gospodarki. Zjawisko to rozpatrywane jest w literaturze z punktu widzenia gospodarek, rynków (w tym rynków towarowych), przedsiębiorstw finansowych i niefinansowych oraz gospodarstw domowych. W opracowaniu poruszono problematykę finansyzacji polskich spółek giełdowych, której przejawem jest wzrost znaczenia operacji finansowych w procesie generowania wartości dodanej. Cel artykułu: Deklaratywna ocena stopnia finansyzacji wybranych spółek giełdowych, a także identyfikacja czynników, które mogą mieć związek ze zjawiskiem finansyzacji w analizowanych podmiotach.

Metody badawcze: Analiza literatury oraz prezentacja i omówienie wyników badań własnych o charakterze jakościowym. W części empirycznej wykorzystano miary tendencji centralnej, klasyfikację opartą na metodzie k-średnich oraz test U Manna-Whitneya.

Główne wnioski: Zjawisko finansyzacji, zgodnie z uzyskanymi wynikami, wydaje się obecnie nie odgrywać znaczącej roli w kształtowaniu działalności operacyjnej polskich spółek giełdowych z analizowanych sektorów. Ponadto wykazano, iż potencjał innowacyjny, pozycja rynkowa, wielkość spółki oraz rynki zbytu mogą mieć związek ze stopniem finansyzacji. Wartością dodaną, jaką niniejsze opracowanie wnosi do krajowej literatury, jest ukazanie zjawiska finansyzacji przedsiębiorstw niefinansowych w kontekście zmian zachodzących w przedsiębiorstwie w opinii menedżerów finansowych.
\end{abstract}

\title{
Wprowadzenie
}

Finansyzacja w gospodarkach krajów najwyżej rozwiniętych jest zjawiskiem rozpoznanym i dyskutowanym na gruncie nauk ekonomicznych. Dotyka ona w różnym stopniu gospodarstw domowych, wybranych rynków (w tym rynków towarowych), przedsiębiorstw finansowych oraz niefinansowych, a pośród tych ostatnich - w największym stopniu spółek notowanych na giełdzie. Tymczasem w gospodarkach krajów rozwijających się - jakkolwiek wskazuje się na występowanie finansyzacji podporządkowanej - jest ona nadal tematem relatywnie słabiej zidentyfikowanym 
i analizowanym. Ten argument stanowi główną przesłankę do podjęcia badań. Ponadto finansyzacja przedsiębiorstw jest niezmiernie rzadko badana z wykorzystaniem metod jakościowych bazujących na opiniach menedżerów odpowiedzialnych za politykę finansową przedsiębiorstw.

Niniejszy artykuł jest zdaniem autorów pierwszą na gruncie polskim próbą wypełnienia tej luki w wiedzy. Cel opracowania to deklaratywna ocena stopnia finansyzacji wybranych spółek giełdowych, a także identyfikacja czynników, które mogą mieć związek ze zjawiskiem finansyzacji w analizowanych podmiotach. Tak postawiony cel badawczy zrealizowano za pomocą analizy literatury oraz prezentacji i omówienia wyników badań własnych o charakterze jakościowym. Struktura artykułu została podporządkowana celowi badania. Kolejno ukazano teoretyczne aspekty finansyzacji, omówiono metodykę badania oraz zaprezentowano i omówiono wyniki badań empirycznych.

\section{Przegląd literatury}

W szerokim znaczeniu finansyzacja jest utożsamiana z: systemową transformacją dojrzałych gospodarek kapitalistycznych (Lapavitsas, 2011, s. 611); przejściem od kapitalizmu przemysłowego do kapitalizmu finansowego (van der Zwan, 2014, s. 99); zmianą relacji finansowych i praktyk działania agentów ekonomicznych we współczesnym kapitalizmie (Gortz i Kaltenbrunner, 2018, s. 377); rosnącą rolą motywów, rynków aktorów i instytucji finansowych (Epstein, 2005, s. 3). W wąskim ujęciu finansyzacja postrzegana jest jako: tendencja do czerpania zysków w większym stopniu przez kanały finansowe niż z wykorzystaniem działalności produkcyjnej (Krippner, 2011, s. 4); proces ewolucji pieniądza, w którym zwiększa on stopniowo swoje znaczenie w gospodarce i społeczeństwie (Vercelli, 2017, s. 91); zdolność do handlowania ryzykiem (Hardie, 2011, s. 143); dominacja kryteriów finansowych w zarządzaniu podmiotami i sprawowaniem nadzoru korporacyjnego, a także wzrost handlu prawami własności z wykorzystaniem instrumentów finansowych (Langley, 2008, s. 133-140). Na gruncie krajowej literatury termin ,finansyzacja” oraz jego alternatywy są definiowane m.in. jako: nadproporcjonalny rozrost sfery finansowej (Żyżyński, 2010, s. 27); postępujący wzrost znaczenia sektora finansowego i związanych z nim elit (Wrzesiński, 2014, s. 293); powszechne utowarowienie długu (Sokół, 2017, s. 134); wzrost znaczenia operacji finansowych w procesie generowania dodatkowej wartości zarówno na rynkach finansowych, jak i w gospodarstwach domowych, małych i średnich przedsiębiorstwach oraz całych gospodarkach, cechujący się częściowym odseparowaniem od sfery realnej (Franc-Dąbrowska, 2018, s. 701).

W kontekście finansyzacji przedsiębiorstw zasadne wydaje się podkreślenie dwóch istotnych czynników, które mogą być związane z analizowanym zagadnieniem. Pierwszym z nich jest proces zastępowania menedżerów korporacyjnych me- 
nedżerami odpowiedzialnymi za zarządzanie pieniądzem, co według Hymana Minsky'ego jest przejawem tworzenia kapitalizmu menedżerów finansowych. Wiązało się to z rozwojem takich instytucji finansowych, jak np. fundusze emerytalne czy fundusze inwestycyjne. Podmioty te stawały się właścicielami coraz większej puli aktywów na rynkach kapitałowych. W rezultacie pasywna strategia kup i trzymaj została zastąpiona przez strategię zakładającą aktywne kształtowanie portfela aktywów w celu zmaksymalizowania wartości inwestycji dla uczestników funduszy. Rosnące znaczenie menedżerów finansowych oraz możliwość migracji kapitału do podmiotów wykazujących wyższą efektywność zmusiły z kolei przedstawicieli biznesu do coraz silniejszej koncentracji na krótkookresowych wynikach (Whalen, 2017, s. 46). Drugim kluczowym czynnikiem w procesie finansyzacji przedsiębiorstw było wdrożenie, a następnie upowszechnienie koncepcji zarządzania wartością dla akcjonariuszy. Dominującym celem funkcjonowania przedsiębiorstwa, a jednocześnie głównym miernikiem efektywności menedżerów stało się maksymalizowanie majątku akcjonariuszy. Jak przekonuje Stout (2012, s. 3), menedżerowie w pogoni za uwalnianiem wartości dla akcjonariuszy gotowi są sprzedawać kluczowe aktywa spółki, redukować nakład na badania i rozwój, przeznaczać olbrzymie środki na wykup akcji własnych oraz na dywidendy, a także zwiększać wykorzystanie dźwigni finansowej do poziomu zagrażającego wypłacalności przedsiębiorstwa oraz zajmować się spekulacją z wykorzystaniem swapów ryzyka kredytowego, jak również przy użyciu innych pochodnych papierów wartościowych o wysokim ryzyku.

Finansowy model przedsiębiorstwa, będący pochodną obu procesów, doprowadził do sytuacji, w której spółki giełdowe traktowane są niemalże wyłącznie jako wiązka aktywów podlegających nieustannej presji związanej z krótkookresowym imperatywem zwiększania wartości rynkowej. W opinii Fierli (2017, s. 70) w okresie finansyzacji rozwój organiczny spółek zszedł na drugi plan, ustępując rozwojowi zewnętrznemu poprzez fuzje i przejęcia, nawet przy sprzeciwie kluczowych akcjonariuszy, a szybkość rozwoju zaczęła być ważniejsza od kosztów, choćby skrajnie wysokich. Współczesnym wzorem przedsiębiorstwa produkcyjnego nie jest podmiot produkujący i sprzedający produkty przynoszące większą użyteczność ze społecznego punktu widzenia. Jest nim natomiast podmiot obracający aktywami finansowymi, których wartość podlega wzrostowi na rynku za sprawą inflacji aktywów (Toporowski, 2000, s. 132). Finansyzacja przedsiębiorstw rozpatrywana w wymiarze sieciowym (zmiany struktury własności i nadzoru), w wymiarze szacunku instytucjonalnego (reguł i obowiązków nakładanych na przedsiębiorstwa) oraz w wymiarze poznawczo-kulturowym (nowe idee w zakresie zarządzania i nadzoru) prowadzi do konkluzji, że z jednej strony proces finansyzacji może być wzmacniany i potęgowany oddziaływaniem pomiędzy poszczególnymi czynnikami, z drugiej zaś samo przedsiębiorstwo może być poddane procesom finansyzacji w różnym stopniu i natężeniu, a nie zwyczajnie sfinansyzowane (Faust i Kädtler, 2019, s. 294-295). 
Skłania to do postawienia hipotezy badawczej, zgodnie z którą istnieją cechy różnicujące stopień finansyzacji spółek notowanych na Giełdzie Papierów Wartościowych S.A. (GPW) w Warszawie. Cechą wyróżniającą i odróżniającą niniejszy artykuł od innych opracowań na gruncie polskim jest podjęcie próby weryfikacji hipotezy z wykorzystaniem badań jakościowych, co według wiedzy autorów nie miało dotąd miejsca.

\section{Próba badawcza i metodyka badania}

Operat losowania w ramach przeprowadzonego badania stanowiły spółki publiczne, które wchodziły w skład następujących indeksów sektorowych GPW: budownictwo, energia, informatyka, media, nieruchomości, odzież, spożywczy. $Z$ badania wykluczono spółki z indeksu banki ze względu na inną specyfikę działalności oraz z takich indeksów, jak chemia, górnictwo, leki, motoryzacja, paliwa i telekomunikacja ze względu na wymogi wstępne minimalnej liczby obserwacji dla zastosowanych testów statystycznych. Badanie miało formę wspomaganych komputerowo wywiadów telefonicznych i zostało przeprowadzone w okresie październik-grudzień 2018 r. przez firmę Biostat sp. z o.o. W specyfikacji badania zaznaczono, że respondentami muszą być osoby odpowiedzialne w badanych podmiotach za zarządzanie finansami. W ramach badania pozyskano 65 wypełnionych kwestionariuszy ankiet, które pozwoliły na zrealizowanie celu badawczego, jakim była ocena stopnia finansyzacji badanych podmiotów oraz identyfikacja czynników mogących mieć związek ze stopniem finansyzacji.

Kwestionariusz ankiety zawierał pytania dotyczące zmian wartości wskaźników w okresie ostatnich 5 lat, odzwierciedlających stopień finansyzacji spółek w obszarze inwestycyjnym, finansowym oraz podziału zysku. Oceny zmian dokonano z wykorzystaniem wskaźników przetestowanych w warunkach polskich (Szczepankowski, 2017). To podejście jest częściowo spójne z wcześniejszymi badaniami o charakterze ilościowym, które wykazały, że w okresie 2011-2017 stopień finansyzacji polskich spółek giełdowych pozostawał na relatywnie niskim poziomie (Socha i Urban, 2018). Respondenci odpowiedzieli również na pytania dotyczące potencjału innowacyjnego oraz pozycji rynkowej reprezentowanych przedsiębiorstw. Ocena funkcjonowania podmiotów została wyrażona na siedmiostopniowej skali Likerta. Biorąc pod uwagę losowość doboru jednostek w ramach poszczególnych indeksów sektorowych, autorzy przyjęli, że uzyskane wyniki są reprezentatywne dla przedsiębiorstw giełdowych z sektorów uwzględnionych w badaniu.

Uzyskane dane zostały poddane analizie statystycznej z wykorzystaniem miar tendencji centralnej oraz odchylenia standardowego. W kolejnym kroku, w celu identyfikacji dwóch grup podmiotów różniących się dynamiką stopnia finansyzacji, zastosowano klasyfikację z wykorzystaniem metody k-średnich. Do weryfikacji istotności statystycznej różnic pomiędzy zidentyfikowanymi grupami wykorzystano 
nieparametryczny test U Manna-Whitneya. Analizę uzupełniono tabelami krzyżowymi w sytuacjach, w których ze względu na niewystarczającą liczbę obserwacji nie było możliwości zastosowania testów statystycznych. Do obliczeń wykorzystano program IBM SPSS Statistics 25.

Autorzy opracowania zdają sobie sprawę z ograniczeń wynikających z deklaratywnego charakteru badania. Przeprowadzone badanie ukazuje bowiem w większym stopniu świadomość kadry menedżerskiej w zakresie zachodzących procesów finansyzacji w reprezentowanych podmiotach, a w mniejszym stopniu faktycznie następujące zmiany w obszarze inwestycji, finansowania i podziału zysku. Takie działanie było celowe - ideą przyświecającą autorom, w warunkach wykazanej w badaniach ilościowych umiarkowanej finansyzacji polskich spółek giełdowych, było bowiem uchwycenie optyki tego zjawiska z perspektywy osób podejmujących decyzje finansowe w badanych podmiotach.

\section{Wyniki badania}

Wyniki obrazujące dynamikę stopnia finansyzacji ankietowanych podmiotów przedstawiono w tabeli 1. Dane dla całej badanej zbiorowości wskazują, że najwyższa dynamika zmian dotyczy obszaru inwestycyjnego, a zwłaszcza wzrastającego udziału aktywów finansowych w aktywach. Może to oznaczać, że przedsiębiorstwa w większym stopniu angażują swoje zasoby na działalność, która nie jest bezpośrednio związana z zakresem prowadzonej działalności operacyjnej. W obszarach podziału zysku oraz finansowym wartości średnie i mediany odpowiedzi pozwalają stwierdzić, że w ostatnich 5 latach nie nastąpiły istotne zmiany. Można zatem przypuszczać, że polskie spółki publiczne $\mathrm{z}$ analizowanych sektorów - w opinii ich zarządzających - nie zwiększają stopnia zadłużenia długoterminowego ani nie wprowadzają zmian w sposobach podziału zysku. Ponadto ankietowani nie zaobserwowali zwiększonej dynamiki w wykorzystaniu finansowych instrumentów pochodnych. Potwierdzeniem tych wniosków może być również neutralna ocena respondentów w zakresie wpływu działalności finansowej na generowany wynik finansowy w ujęciu netto.

Tabela 1. Na ile zgadza się Pan/Pani z poniższymi określeniami związanymi z ufinansowieniem reprezentowanej spółki (w okresie ostatnich 5 lat działalności)

\begin{tabular}{|l|c|c|c|}
\hline \multicolumn{1}{|c|}{ Pytanie } & Średnia & Mediana & $\begin{array}{c}\text { Odchylenie } \\
\text { standardowe }\end{array}$ \\
\hline $\begin{array}{l}\text { Wzrost udziału długoterminowych aktywów finansowych w aktywach } \\
\text { trwałych }\end{array}$ & 3,49 & 3,00 & 2,17 \\
\hline $\begin{array}{l}\text { Wzrost udziału krótkoterminowych aktywów finansowych w aktywach } \\
\text { obrotowych }\end{array}$ & 3,37 & 3,00 & 2,07 \\
\hline $\begin{array}{l}\text { Wzrost udziału wydatków inwestycyjnych na aktywa finansowe w wy- } \\
\text { datkach inwestycyjnych ogółem }\end{array}$ & 2,83 & 3,00 & 1,65 \\
\hline
\end{tabular}


Pobrane z czasopisma Annales H - Oeconomia http://oeconomia.annales.umcs.pl

Data: 26/04/2023 03:15:34

PRZEJAWY FINANSYZACJI POLSKICH SPÓŁEK GIEŁDOWYCH W OPINII MENEDŻERÓW...

\begin{tabular}{|l|c|c|c|}
\hline \multicolumn{1}{|c|}{ Pytanie } & Średnia & Mediana & $\begin{array}{c}\text { Odchylenie } \\
\text { standardowe }\end{array}$ \\
\hline $\begin{array}{l}\text { Wzrost udziału wpływów inwestycyjnych na aktywa finansowe we } \\
\text { wpływach inwestycyjnych ogółem }\end{array}$ & 2,71 & 3,00 & 1,43 \\
\hline $\begin{array}{l}\text { Wzrost wykorzystania instrumentów pochodnych (opcja, futures, swap, } \\
\text { forward) }\end{array}$ & 1,97 & 1,00 & 1,66 \\
\hline Wzrost udziału zadłużenia długoterminowego w strukturze kapitału & 2,71 & 2,00 & 2,17 \\
\hline Wzrost udziału kosztów finansowych w kosztach ogółem & 2,58 & 2,00 & 1,46 \\
\hline Wzrost stopy wypłaty dywidendy & 2,43 & 2,00 & 1,85 \\
\hline Wzrost wydatków finansowych na kapitał własny w wydatkach ogółem & 2,65 & 3,00 & 1,47 \\
\hline $\begin{array}{l}\text { Prowadzona działalność finansowa (inwestycje finansowe) pozwoliła } \\
\text { spółce osiągnąć wyższy zysk netto }\end{array}$ & 3,25 & 3,00 & 2,22 \\
\hline
\end{tabular}

Źródło: opracowanie własne.

Neutralna ocena respondentów w zakresie dynamiki zjawiska finansyzacji w spółkach publicznych oraz stosunkowo wysokie odchylenia standardowe uzyskanych wyników skłoniły autorów artykułu do sklasyfikowania badanych podmiotów metodą k-średnich w dwóch klastrach zróżnicowanych właśnie pod względem stopnia finansyzacji. Wyniki klasyfikacji przedstawiono w tabeli 2.

Tabela 2. Na ile zgadza się Pan/Pani z poniższymi określeniami związanymi z ufinansowieniem reprezentowanej spółki (w okresie ostatnich 5 lat działalności) w podziale na dwa klastry

\begin{tabular}{|l|c|c|c|c|c|}
\hline \multirow{2}{*}{ Pytanie } & \multicolumn{2}{c|}{ Klaster nr 1 } & \multicolumn{2}{c|}{ Klaster nr 2 } & $\begin{array}{c}\text { Statystyka } \\
\text { z testu U Man- } \\
\text { na-Whitneya }\end{array}$ \\
\cline { 2 - 6 } & średnia & mediana & średnia & mediana & $-4,48^{* *}$ \\
\hline $\begin{array}{l}\text { Wzrost udziału długoterminowych aktywów finan- } \\
\text { sowych w aktywach trwałych }\end{array}$ & 6,17 & 6,50 & 2,89 & 2,00 & $-0,24$ \\
\hline $\begin{array}{l}\text { Wzrost udziału krótkoterminowych aktywów finan- } \\
\text { sowych w aktywach obrotowych }\end{array}$ & 3,33 & 3,00 & 3,38 & 3,00 & \\
\hline $\begin{array}{l}\text { Wzrost udziału wydatków inwestycyjnych na aktywa } \\
\text { finansowe w wydatkach inwestycyjnych ogółem }\end{array}$ & 2,67 & 1,00 & 2,87 & 3,00 & $-1,01$ \\
\hline $\begin{array}{l}\text { Wzrost udziału wpływów inwestycyjnych na aktywa } \\
\text { finansowe we wpływach inwestycyjnych ogółem }\end{array}$ & 2,25 & 1,50 & 2,81 & 3,00 & $-1,26$ \\
\hline $\begin{array}{l}\text { Wzrost wykorzystania instrumentów pochodnych } \\
\text { (opcja, futures, swap, forward) }\end{array}$ & 3,42 & 3,50 & 1,64 & 1,00 & $-2,38^{*}$ \\
\hline $\begin{array}{l}\text { Wzrost udziału zadłużenia długoterminowego } \\
\text { w strukturze kapitału }\end{array}$ & 6,25 & 7,00 & 1,91 & 1,00 & $-5,43^{* *}$ \\
\hline $\begin{array}{l}\text { Wzrost udziału kosztów finansowych w kosztach } \\
\text { ogółem }\end{array}$ & 4,08 & 4,00 & 2,25 & 2,00 & $-2,85^{* *}$ \\
\hline Wzrost stopy wypłaty dywidendy & 1,67 & 1,00 & 2,60 & 2,00 & $-1,87$ \\
\hline $\begin{array}{l}\text { Wzrost wydatków finansowych na kapitał własny } \\
\text { w wydatkach ogółem }\end{array}$ & 3,08 & 4,00 & 2,55 & 3,00 & $-1,11$ \\
\hline $\begin{array}{l}\text { Prowadzona działalność finansowa (inwestycje finan- } \\
\text { sowe) pozwoliła spółce osiągnąć wyższy zysk netto }\end{array}$ & 4,33 & 4,50 & 3,00 & 3,00 & $-1,66$ \\
\hline
\end{tabular}

$$
* * \mathrm{p}<0,01 ; * \mathrm{p}<0,05
$$

Źródło: opracowanie własne. 
Do klastra nr 1 zakwalifikowano 12 spółek, których stopień finansyzacji był znacząco wyższy niż podmiotów zakwalifikowanych do klastra $\mathrm{nr} 2$ (53 spółki). Istotne statystyczne różnice pomiędzy klastrami wykazano dla jednego wskaźnika w obszarze inwestycyjnym - udziału długoterminowych aktywów finansowych w aktywach trwałych, wzrostu wykorzystania finansowych instrumentów pochodnych oraz obszaru finansowego (wzrost udziału zadłużenia długoterminowego w strukturze kapitału oraz wzrost kosztów finansowych w kosztach ogółem). Nie wykazano istotnych statystycznie różnic pomiędzy klastrami w zakresie wskaźników obrazujących zmiany w zasadach podziału zysku oraz wpływu finansyzacji na osiągany zysk netto. Powyższe sugeruje, że zjawisko finansyzacji występuje w polskich spółkach publicznych z sektorów objętych badaniem, lecz dotyczy stosunkowo niewielkiej grupy podmiotów. Wyniki dowodzą też, że wzrostowi finansyzacji w obszarze inwestycyjnym towarzyszy wzrost finansyzacji w ujęciu finansowym. W dalszym ciągu nie są jednak znane czynniki mogące warunkować stopień finansyzacji. Z tego względu w kolejnym kroku badania zweryfikowano subiektywną ocenę potencjału innowacyjnego i pozycji rynkowej spółek zgrupowanych w klastry zróżnicowane pod względem stopnia finansyzacji (tabela 3 ).

Tabela 3. Na ile zgadza się Pan/Pani z poniższymi określeniami związanymi z potencjałem innowacyjnym oraz pozycją rynkową reprezentowanej spółki w podziale na dwa klastry

\begin{tabular}{|c|c|c|c|c|c|}
\hline \multirow[b]{2}{*}{ Pytanie } & \multicolumn{2}{|c|}{ Klaster nr 1} & \multicolumn{2}{|c|}{ Klaster nr 2} & \multirow{2}{*}{$\begin{array}{l}\text { Statystyka } \\
\text { z testu } \\
\text { U Man- } \\
\text { na-Whit- } \\
\text { neya }\end{array}$} \\
\hline & średnia & mediana & średnia & mediana & \\
\hline $\begin{array}{l}\text { Spółka przeznaczyła na badania i rozwój znacząco } \\
\text { więcej niż wynosi średni wydatek w branży }\end{array}$ & 3,75 & 4,00 & 2,25 & 2,00 & $-3,02 * *$ \\
\hline $\begin{array}{l}\text { Spółka była pionierem w rozwijaniu przełomowych } \\
\text { innowacji w branży }\end{array}$ & 3,17 & 3,50 & 2,51 & 2,00 & $-1,05$ \\
\hline $\begin{array}{l}\text { Spółka cechuje się znacznym zaangażowaniem } \\
\text { w podejmowanie działań badawczo-rozwojowych oraz } \\
\text { przywództwo technologiczne i przywództwo w zakresie } \\
\text { innowacji }\end{array}$ & 3,83 & 4,00 & 2,55 & 2,00 & $-2,21 *$ \\
\hline $\begin{array}{l}\text { W branży, w której funkcjonuje spółka, są szerokie } \\
\text { możliwości wdrażania innowacji produktowych i/lub } \\
\text { technologicznych }\end{array}$ & 4,50 & 4,50 & 3,96 & 4,00 & $-1,09$ \\
\hline $\begin{array}{l}\text { Wydatki na badania i rozwój w branży, w której funkcjo- } \\
\text { nuje spółka, są wyższe niż w innych branżach }\end{array}$ & 3,75 & 4,00 & 2,79 & 2,00 & $-1,64$ \\
\hline Spółka rosła szybciej niż najważniejsi konkurenci & 2,75 & 3,50 & 2,96 & 3,00 & $-0,15$ \\
\hline $\begin{array}{l}\text { Spółka osiągała wyższą rentowność sprzedaży niż } \\
\text { najważniejsi konkurenci }\end{array}$ & 2,17 & 1,00 & 3,30 & 4,00 & $-2,25^{*}$ \\
\hline $\begin{array}{l}\text { Spółka osiągała wyższy udział w rynku niż najważniejsi } \\
\text { konkurenci }\end{array}$ & 2,75 & 2,50 & 2,98 & 3,00 & $-0,34$ \\
\hline $\begin{array}{l}\text { Spółka oferowała produkty wyższej jakości niż najważ- } \\
\text { niejsi konkurenci }\end{array}$ & 3,67 & 3,50 & 3,96 & 4,00 & $-1,03$ \\
\hline
\end{tabular}

$* * \mathrm{p}<0,01 ; * \mathrm{p}<0,05$

Źródło: opracowanie własne. 
W obszarze potencjału innowacyjnego wszystkie czynniki oceniono wyżej w spółkach wchodzących w skład klastra nr 1, cechującego się wzrostem stopnia finansyzacji. Różnice w zakresie wydatków na badania i rozwój oraz przywództwa technologicznego i przywództwa w zakresie innowacji okazały się istotne statystycznie. Odmienne wyniki uzyskano w ocenie pozycji rynkowej. Respondentom zadano cztery pytania w tym zakresie, a średnie oceny respondentów reprezentujących klaster przedsiębiorstw o niskiej dynamice finansyzacji okazały się wyższe niż dla klastra nr 1. Różnicę istotną statystycznie wykazano dla osiąganej rentowności sprzedaży w relacji do najważniejszych konkurentów. W odniesieniu do wyników oceny działalności innowacyjnej oraz badań i rozwoju zaskakujące wydaje się, że na poziomie deklaratywnym wyższemu poziomowi finansyzacji w obszarze udziału długoterminowych aktywów finansowych, wzrostowi wykorzystania instrumentów pochodnych oraz zadłużenia długoterminowego i kosztów finansowych nie odpowiada gorsza ocena działalności innowacyjnej i badawczo-rozwojowej. Może to skłaniać do wniosku, że być może w analizowanej grupie spółek wyższy poziom finansyzacji nie odbywa się kosztem organicznego rozwoju spółki, co bywa podnoszone w literaturze przedmiotu (Davis, 2017; Tori i Onaran, 2018).

Tabela 4. Wielkość badanych spółek w podziale na dwa klastry

\begin{tabular}{|l|r|c|c|c|c|c|}
\hline \multirow{2}{*}{ Wielkość } & \multicolumn{3}{|c|}{ Klaster nr 1 } & \multicolumn{3}{c|}{ Klaster nr 2 } \\
\cline { 2 - 7 } & częstość & \% & \% skumulowany & częstość & \% & \% skumulowany \\
\hline Przedsiębiorstwo małe & 1 & 8,3 & 8,3 & 11 & 20,8 & 20,8 \\
\hline Przedsiębiorstwo średnie & 2 & 16,7 & 25,0 & 23 & 43,4 & 64,2 \\
\hline Przedsiębiorstwo duże & 9 & 75,0 & 100,0 & 19 & 35,8 & 100,0 \\
\hline Ogółem & 12 & 100,0 & - & 53 & 100,0 & - \\
\hline
\end{tabular}

Źródło: opracowanie własne.

Analiza struktury wielkości spółek wchodzących w skład klastrów sugeruje, że zjawisko finansyzacji jest częstsze $\mathrm{w}$ grupie podmiotów dużych niż w grupie podmiotów średnich i małych. Jak pokazano w tabeli 4, aż 9 z 12 podmiotów zakwalifikowanych do klastra nr 1 to podmioty duże, a tylko 3 to podmioty małe lub średnie. Podmioty duże w klastrze nr 2 stanowiły 36\% ogółu, a spółki małe i średnie $-64 \%$. Wyniki te są spójne z prezentowanym w literaturze poglądem, że finansyzacja ujawnia się w szczególności w przedsiębiorstwach dużych (Ratajczak, 2014). Ponadto - jak wynika $z$ danych przedstawionych w tabeli 5 - spółki o większej dynamice finansyzacji w większym stopniu znajdowały nabywców na swoje wyroby poza Polską. Skłania to do postawienia pytania dotyczącego relacji pomiędzy poziomem internacjonalizacji przedsiębiorstwa a stopniem jego finansyzacji, co może stanowić potencjalny kierunek dalszych badań. Niestety, ze względu na ograniczoną liczebność poszczególnych klas autorzy nie są w stanie potwierdzić tych obserwacji stosownymi testami statystycznymi. 
Pobrane z czasopisma Annales H - Oeconomia http://oeconomia.annales.umcs.pl Data: 26/04/2023 03:15:34

Tabela 5. Rynki zbytu badanych spółek w podziale na dwa klastry

\begin{tabular}{|l|c|c|c|c|c|c|}
\hline \multirow{2}{*}{ Rynek } & \multicolumn{3}{|c|}{ Klaster nr 1 } & \multicolumn{3}{c|}{ Klaster nr 2 } \\
\cline { 2 - 7 } & częstość & $\%$ & \% skumulowany & częstość & $\%$ & \% skumulowany \\
\hline Polski & 4 & 33,3 & 33,3 & 30 & 56,6 & 56,6 \\
\hline Europejski & 4 & 33,3 & 66,7 & 9 & 17,0 & 73,6 \\
\hline Ogólnoświatowy & 4 & 33,3 & 100,0 & 14 & 26,4 & 100,0 \\
\hline Ogółem & 12 & 100,0 & - & 53 & 100,0 & - \\
\hline
\end{tabular}

Źródło: opracowanie własne.

Wyniki uzyskane w przeprowadzonym badaniu pozwalają na wyciągnięcie następujących wniosków. Po pierwsze, zjawisko finansyzacji wydaje się obecnie nie odgrywać znaczącej roli w kształtowaniu działalności operacyjnej polskich spółek giełdowych z badanych sektorów. Klasyfikacja podmiotów metodą k-średnich wykazała, że grupa podmiotów o zwiększonej dynamice finansyzacji jest zdecydowanie mniejsza niż grupa odniesienia. Po drugie, przedsiębiorstwa cechujące się wyższą finansyzacją w obszarze działalności inwestycyjnej na ogół cechowały się także wyższą finansyzacją w obszarze działalności finansowej. W opinii autorów może to sugerować podejmowanie inwestycji finansowych z wykorzystaniem lewarowania. Po trzecie, wyższą dynamikę finansyzacji zaobserwowano $\mathrm{w}$ grupie przedsiębiorstw oceniających swój potencjał innowacyjny wyżej niż firmy o niskiej dynamice finansyzacji. Wytłumaczeniem takiego stanu rzeczy może być poziom akceptowanego $\mathrm{w}$ tych przedsiębiorstwach ryzyka - w klastrze $\mathrm{nr} 1$, a więc o większej dynamice finansyzacji i wyższym poziomie potencjału innowacyjnego, chęć do podejmowania ryzyka jest prawdopodobnie wyższa niż w drugim skupieniu podmiotów. Ponadto wyższą dynamikę finansyzacji zanotowano w grupie spółek oceniających swoją pozycję rynkową niżej niż grupa odniesienia. Jeżeli gorsza pozycja rynkowa przekłada się na gorsze wyniki operacyjne, to finansyzacja może być w takim przypadku sposobem na poprawę osiąganego wyniku netto. Badanie wykazało też, że finansyzacja podmiotów większych i zbywających swoje wyroby na rynku europejskim i ogólnoświatowym była $\mathrm{w}$ badanej próbie wyższa niż w podmiotach małych i średnich oraz korzystających tylko z polskiego rynku zbytu.

\section{Zakończenie}

Celem artykułu była deklaratywna ocena stopnia finansyzacji wybranych spółek giełdowych oraz identyfikacja czynników, które mogą mieć związek ze zjawiskiem finansyzacji w analizowanych podmiotach. Wartością dodaną, jaką niniejsze opracowanie wnosi do krajowej literatury, jest ukazanie zjawiska finansyzacji przedsiębiorstw niefinansowych w kontekście zmian zachodzących w przedsiębiorstwie w opinii menedżerów finansowych. W toku badań własnych pozytywnie zweryfikowano hipotezę, zgodnie z którą istnieją cechy różnicujące stopień finansyzacji spółek 
notowanych na Giełdzie Papierów Wartościowych w Warszawie S.A. Ograniczenia badania stanowią pochodną zastosowanego narzędzia badawczego. Zaprezentowane wyniki są rezultatem subiektywnej oceny zarządzających finansami, nie zaś obiektywnej oceny wynikającej z analizy konkretnych wskaźników finansowych. Mimo to zdaniem autorów badanie o charakterze jakościowym może stanowić wartościowe uzupełnienie dla dociekań nad zjawiskiem finansyzacji przedsiębiorstw niefinansowych prowadzonych z wykorzystaniem metod ilościowych.

\section{Bibliografia}

Davis, L. (2017). Financialization and the non-financial corporation: An investigation of firm-level investment behavior in the United States. Metroeconomica. International Review of Economics, 69(1). doi:10.1111/meca.12179

Epstein, G. (ed.). (2005). Financialization and the World Economy. Cheltenham: Edward Elgar.

Faust, M., Kädtler, J. (2019). The (Not Entirely) Financialized Enterprise - A Conceptual Proposal. Historical Social Research, 44(1). doi:10.12759/hsr.44.2019.1.285-307

Fierla, A. (red.). (2017). Finansjeryzacja gospodarki i jej wptyw na przedsiębiorstwa. Warszawa: Oficyna Wydawnicza SGH.

Franc-Dąbrowska, J. (2018). Ufinansowienie gospodarki i finansowy wzrost wartości. Ekonomista, (6).

Gortz, P., Kaltenbrunner, A. (2018). The International Dimension of Financialization in Developing and Emerging Economies. Development and Change, 49(2). doi:10.1111/dech.12371

Hardie, I. (2011). How much can governments borrow? Financialization and emerging markets government borrowing capacity. Review of International Political Economy, 18(2). doi:10.1080/09692290903507276

Krippner, G. (2011). Capitalizing on Crisis. The Political Origins of the Rise of Finance. Harvard University Press.

Langley, P. (2008). Financialization and the Consumer Credit Boom. Competition \& Change, 12(2).

Lapavitsas, C. (2011). Theorizing financialization. Work, Employment and Society, 25(4). doi:10.1177/0950017011419708

Ratajczak, M. (2014). Ekonomia w dobie finansyzacji gospodarki. Ruch Prawny, Ekonomiczny i Socjologiczny, (2). doi:10.14746/rpeis.2014.76.2.19

Socha, B., Urban, D. (2018). The Financialization of Companies Listed on the Warsaw Stock Exchange the Sector Analysis. Annales Universitatis Mariae Curie-Skłodowska, sectio H-Oeconomia, 52(4). doi:10.17951/h.2018.52.4.93-102

Sokół, H. (2017). Krótkoterminowe papiery dłużne w zarządzaniu płynnością przedsiębiorstwa. W: A. Fierla (red.), Finansjeryzacja gospodarki i jej wptyw na przedsiębiorstwa. Warszawa: Oficyna Wydawnicza SG.

Stout, L. (2012). The Shareholder Value Myth, How Putting Shareholders First Harms Investors, Corporations, and the Public. Berrett-Koehler Publishers.

Szczepankowski, P. (2017). Koncepcja i zastosowanie syntetycznego wskaźnika stopnia finansyzacji przedsiębiorstw. Finanse, Rynki Finansowe, Ubezpieczenia, (2). doi:10.18276/frfu.2017.86-24

Toporowski, J. (2000). The End of Finance. Capital market inflation, financial derivatives and pension fund capitalism. London: Routledge Frontiers of Political Economy.

Tori, D., Onaran, O. (2018). The effects of financialization on investment: evidence from firm-level data for the UK. Cambridge Journal of Economics, 42(5). doi:10.1093/cje/bex085

Vercelli, A. (2017). Crisis and Sustainability. The Delusion of Free Markets. London: Palgrave Macmillan. Whalen, Ch. (2017). Understanding financialization: standing on the shoulders of Minsky. E-Finance Financial Internet Quarterly, 13(2). doi:10.1515/fiqf-2016-0022 
Pobrane z czasopisma Annales H - Oeconomia http://oeconomia.annales.umcs.pl Data: 26/04/2023 03:15:34

Wrzesiński, M. (2014). Finansjalizacja gospodarki - fakty czy mity? W: J. Ostaszewski, E. Kosycarz (red.), Rozwój nauki o finansach. Stan obecny i pożądane kierunki jej ewolucji. Warszawa: SGH.

Żyżyński, J. (2010). Neoliberalizm - ślepa uliczka globalizacji. W: G. Kołodko (red.), Globalizacja, kryzys i co dalej? Warszawa: Wydawnictwo Poltext.

Zwan, N. van der (2014). Making sense of financialization. Socio-Economic Review, 12(1). doi:10.1093/ser/mwt020 